超電導技術を応用した磁気分離の現状とこれからの社会ニーズ

渡辺 恒雄 ${ }^{* 1}$, , 福井 聡*2

\title{
Current Status of Magnetic Separation Using Superconducting Technology and Future Social Needs
}

\author{
Tsuneo WATANABE ${ }^{* 1, \dagger}$ and Satoshi FUKUI ${ }^{* 2}$
}

\begin{abstract}
Synopsis: This article reviews the current status and recent progress of magnetic separation technologies using superconducting magnets and conventional magnets. In this article, firstly, the research and development history of magnetic separation technologies is reviewed. Secondly, the main component technologies for magnetic separation, such as options for magnetic separation methods, magnet devices as magnetic-field generators, magnetic seeding methods, magnetic filters and magnetic separation methods utilizing the Magneto-Archimedes effect, are summarized. Thirdly, the contents of presentations at the CSJ and CSSJ conferences held from 2006-2018 are summarized. Based on this summary, the status quo of the research and development of magnetic separation technologies in Japan is analyzed. It is confirmed that the component technologies for magnetic separation have advanced well and many new applications of magnetic separation using superconducting magnets have been developing. It is worth noting that the magnetic separation method removing radioactive Cs from contaminated soil using a superconducting magnet has been developed. In China and Korea, the research and development of magnetic separation technologies have continued as well. Particularly in China, there is much interest in magnetic separation since the environmental pollution that has become apparent with economic development has become serious. Through the technical review in this article, it is found that recent magnetic separation technologies have advanced to the level where social implementation is possible. Sustainable Development Goals (SDGs) and promotion of sustainable economies are the tailwinds for spreading magnetic separation with superconducting technology because of contributions to the environment, materials recycling, $\mathrm{CO}_{2}$ emission reduction, cost reduction and innovation.
\end{abstract}

Keywords: high-gradient magnetic separation, magneto-Archimedes effect, magnetic seeding, magnetic separation, superconducting magnet

(Some figures in this article may appear in colour only in the electronic version)

\section{1. はじめに}

磁気分離は物理的処理法であり，処理後の二次廃棄物が 少なく環境調和型技術になり得ること，処理前後の物質変 化が少なく不純物除去や資源回収技術になり得ること，な どの特徴を有している。この特徴を生かして, 超電導マグ ネットが利用される以前から, 様々な磁気分離装置が考案

Received January 22, 2020

*1 東京都立大学（前首都大学東京）大学教育センター 干192-0397 東京都八王子市南大沢 1-1

Tokyo Metropolitan University, 1-1 Minamiosawa, Hachioji, Tokyo 192-0397, Japan

*2 新潟大学 工学部 電気電子工学科

干950-2181 新潟県新潟市西区五十嵐 2 の町 8050

Niigata University, 8050 Igarashi Ni-no-cho, Nishi-ku, Niigata 950-2181, Japan

† E-mail: twtm@tmu.ac.jp, tsuneo.watanabe219@gmail.com DOI: $10.2221 /$ jcsj.55.149
され, カオリン粘土の純化や鉱物資源の選別などの分野で 使われてきた ${ }^{1,2)}$ 。

前回の低温工学誌の磁気分離に関する特集（2011 年 46 巻 11 号）において, 企画担当者の西嶋茂宏教授は, 特集企 画の背景に次のような 3 つの変化があると指摘している ${ }^{3)}$ 。

(1) 関係者の努力により磁気分離技術が社会的に認知さ れつつあること

(2) 超電導磁気分離は、環境浄化や資源回収など、新し い分野での技術の実用化や開発のきっかけになっ てきていること

(3) 韓国や中国での磁気分離装置の開発の機運が高まっ てきていること

本解説では, 2011 年の特集号以降の磁気分離技術に関 する研究開発の発展経過と現在の到達点, これからの産業 化にむけた課題や展望などについて述べる。 


\section{2. 磁気分離技術の研究開発経過}

2011 年までの磁気分離技術の研究開発経過について，前 述の特集号の解説記事 ${ }^{4)}$ で，小原健司教授はマグネットの 開発に応じた分離対象物質の磁性と粒子径に基づいて，大 きく第 1 期一第 3 期に分けて説明している。本解説ではこ れを踏まえ， 2011 年以降を第 4 期として捉えることにする。 まず, 1970 年までの第 1 期の鉱石選別では，分離対象物資 は強磁性・大粒径のもの, 1990 年までの第 2 期の鉱物選別 では, 強磁性・小粒径のもので, 大型の常伝導電磁石や一 部に液体ヘリウム冷却超電導マグネットが用いられた。 2011 年までの第 3 期になると, 小型の無冷媒冷却超電導マ グネットの実用化と普及に伴い，ラボスケールでの研究開 発が加速し, 分離対象物質は常磁性の微小粒径のものにま で広がった。その結果, 超電導マグネットを用いた磁気分 離は，排水処理などの環境浄化，都市鉱山の希少物質の資 源リサイクルなどに不可欠な技術として認識され始めた。 また第 3 期には, 超電導マグネットによる強磁場を活用す る磁気分離の研究開発プロジェクトが日本国内で活発に行 われ，希薄懸濁物質の大量処理技術の開発が進んだ。これ らの研究開発プロジェクト等を通じて，それまでにない新 しい対象（医療・バイオ分野など）に磁気分離技術（物質 に作用する磁気力を利用する技術を含む）を適用する研究 開発が活発になった ${ }^{5)}$ 。また, 福島第 1 原子力発電所事故 による放射能污染土壌からの放射性物質の分離に磁気分離 を適用する研究がスタートした ${ }^{6)}$ 。土壌中の常磁性物質の 粘土成分バーミキュライトとセシウムとの結合が強いこと がわかり，超電導マグネットを利用した高勾配磁気分離に より分離可能であることが見出された。これらの研究は第 4 期に引き継がれている。特に, 超電導マグネットを利用 した放射性セシウムの磁気分離は，環境庁の支援 ${ }^{7)}$ 受け て, 現地の中間貯蔵所での污染土壤の減容化に向けて研究 が行われている ${ }^{8,9)}$ 。

次に, 磁気分離技術に関する学会・研究会活動について 䌕める。磁気分離に関連するワークショップが 2000 年か ら 5 回継続的に開催され，海外からも参加者があった ${ }^{10)}$ 。 2011 年以降の第 4 期の磁気分離の経過も含めて Fig.1 に磁 気分離に関する継続的な学会・研究会活動を縓める。調査 した範囲では，2011 年以降は磁気分離に特化した国際的な 研究会等は確認できなかった。国内では, 低温工学・超電 導学会の春季・秋季大会で継続的に発表が行われている。 2003 年から始まった若手研究者育成を目的とした「磁気力 制御・磁場応用夏の学校」が毎年開催されており, 磁気 分離研究に関わる学生や企業関係者が参加している。2019 年度は福井工大で第 17 回が開催された ${ }^{11)}$ 。2010 年度に開 始の日中韓の磁気分離の研究者により運営されるフォーラ ム「International Forum on Magnetic Force Control (IFMFC)」 が毎年開催され, 磁気分離技術の普及に向けて一定の役割

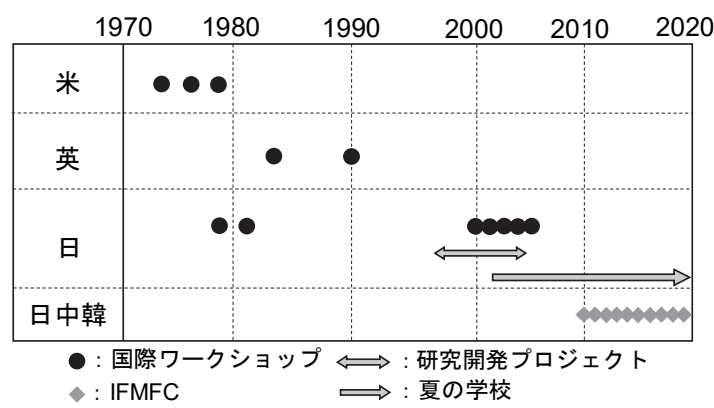

Fig. 1 Status of conferences related to magnetic separation.

を果たしている。この IFMFC は各国の地域委員会が毎年 持ち回りで開催し, 講演会, 研究施設見学および情報交換 を行っている。2019年度は奈良で開催された ${ }^{12)}$ 。

\section{3. 磁気分離の要素技術}

\section{1 対象物質の特性に応じた磁気分離法の選択肢}

多くの磁気分離研究者の成果により, 磁気分離において 超電導技術を適用する場合にメリットを見出せる範囲が明 確になり, 今後の超電導磁気分離技術の開発の道筋が見え てきた。これまでの多岐にわたる研究成果に基づき, 分離 対象物質の特性に応じた磁気分離の要素技術の選択肢は Fig. 2 の通りに整理されている ${ }^{5)}$ 。常磁性物質については, 磁気シーディング法と超電導マグネットの外部空間または ボア内での高勾配磁気分離法を採用する。また, 超電導マ グネット高勾配強磁性物質については, 磁束密度が $2 \mathrm{~T}$ 未 満の永久磁石又は常伝導電磁石を用いても, 高勾配磁気分 離を利用すれば高い分離効果が得られる。磁気シーディン グ法を用いない磁気分離法として, 反磁性物質および常磁 性物質について, 超電導磁石による強磁場空間での磁気ア ルキメデス磁気分離法が選択できる。このように, 超電導 マグネットの強磁場を活用することにより, 常磁性物質や 反磁性物質も含めた様々な物質を磁気分離できる技術的条 件が揃いつつある。

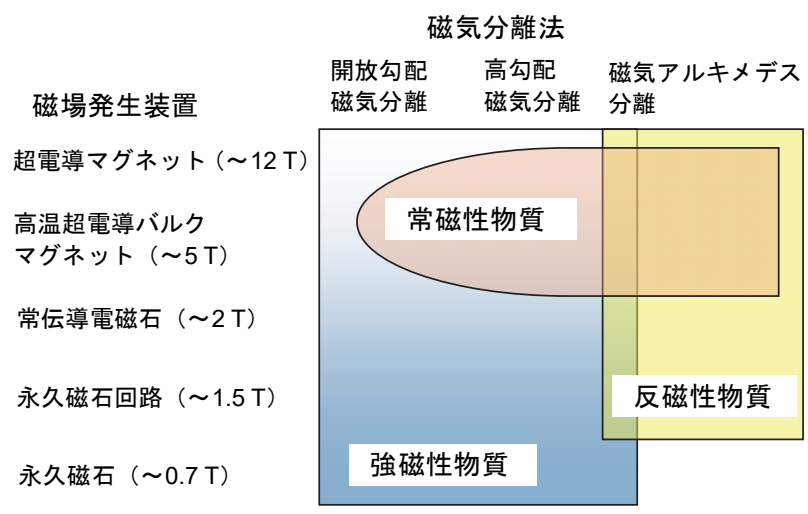

Fig. 2 Mapping for selecting component techniques of magnetic separation. 


\section{2 磁気シーディング法}

磁性の小さい常磁性物質では, 例え超電導マグネットに よる強磁場を印可してもわずかな磁化しか生じない。従っ て, 強磁性物質と比較すると, 作用する磁気力は一般に数 桁以上小さくなり，そのままでは磁気分離を適用すること が困難となる。磁気シーディング法とは，このような常磁 性物質を強磁性物質と一体化させ, 見かけ上強い磁性を有 するようにする技術の総称である ${ }^{14)}$ 。ここでは, 磁性物 質に働く磁気力の理論式に基づき, 磁気シーディング法の 有用性について確認する。

球形磁性粒子に働く磁気力 $\boldsymbol{F}_{m}$ は, 磁性粒子の磁化が飽 和しない場合には, 次式で表される。

$$
\boldsymbol{F}_{m}=V_{p} \cdot \mu_{0} \cdot \frac{9\left(\chi_{p}-\chi_{f}\right)}{\left(3+\chi_{p}\right)\left(3+\chi_{f}\right)} \cdot|\boldsymbol{H}| \operatorname{grad}|\boldsymbol{H}|
$$

ここで， $V_{p}$ は粒子体積， $\chi_{p}$ および $\chi_{f}$ はそれぞれ粒子およ び周囲媒体（流体など）の磁化率，H $\boldsymbol{H}$ は外部磁場である。 上式より, 磁気力を大きくするには, 対象物質の体積, 磁 化率，外部磁場およびその空間勾配をそれぞれ大きくする ことが有効である。磁気シーディング法の的確な選択, 磁 場装置や磁気分離法の選択肢が増えることになり, 適用対 象に合わせたフレキシブルなシステム設計が可能になる。 従って常磁性物質の磁気分離では, 磁気シーディング法の 選択が重要になる。

次に，これまでに開発されてきた磁気シーディング法の 体系図 ${ }^{13)}$ を Fig. 3 に示寸。磁気シーディングが備えるべ き要件として, 安定性, 安全性, 適切な磁性付与, 簡便 性・低コスト, リサイクル性などが求められる。

結合法 (Combined method) は, マグネタイトなどの強 磁性体と分離対象物質とを結合させる方法である。凝集剤 結合法（Flocculant binding method）は，排水中の分離対象 の懸潈物質とマグネタイト微粒子とを凝集剂を介して磁性 凝集フロックに一体化する。無機凝集剤には水酸化鉄，水 酸化アルミニウム, 高分子凝集剤などがある。排水処理で 用いられる鉄電解処理では, 水酸化鉄ポリマーと懸濁粒子 との結合により常磁性フロックを形成する。また磁化活性 污泥法では, 有機物を分解する微生物をマグネタイトで強

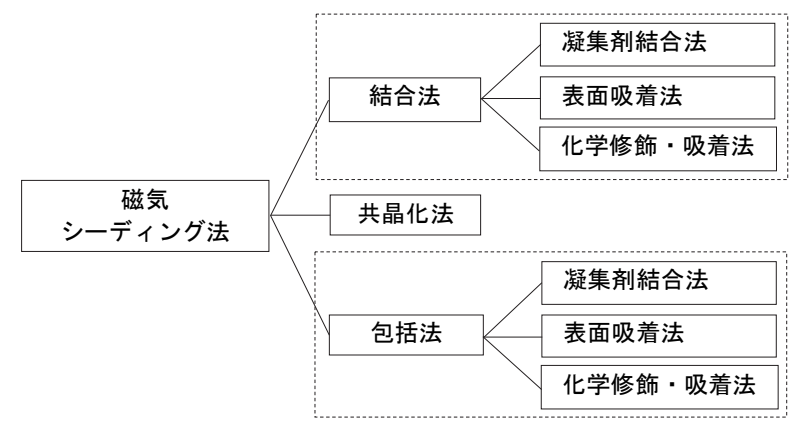

Fig. 3 Magnetic seeding methods.
磁性を付与し, 永久磁石で磁気分離する。表面吸着法 (Surface adsorption method) では, 直径数 nm の微細なマ グネタイトコロイドを処理水の $\mathrm{pH}$ に応じて, 官能基を静 電気的相互作用, 水素結合や配位結合などの作用で分離対 象物質を吸着させて磁性コロイドとして超電導マグネット を用い磁気分離する。この方法を利用した実用化例として, 製紙工場廃水中の染料を超電導マグネット（発生磁場 $2 \mathrm{~T}$ ) による磁気分離を行い，処理水の再生につなげている ${ }^{15)}$ また, 表面吸着法にはメカノケミカル吸着法もあり, 実用 面で半導体シリコンウェーハー切断時に付着したワイヤー ソーの鉄粉を $\mathrm{SiC}$ 砥粒から超電導磁石で選択磁気分離する ことで $\mathrm{SiC}$ スラリーの再生利用を図っている ${ }^{16)}$ 。化学修 飾・吸着法 (Chemical modification/adsorption method) は マグネタイト表面の水素や水酸基をもとに化学修飾や吸着 作用により、排水中の油分や疎水性污濁物質、ビスフェ ノールなどの難分解成分の分離・回収一の利用が期待され る ${ }^{17) 。}$

共晶化法 (Eutectic method) はフェライト法として, 永 久磁石を用いた磁気分離システムと組み合わせて排水中の 重金属の分離回収法として実用化され, 大学・研究機関に 多数導入されている ${ }^{18)}$ 。また微量のリンを加えて常磁性 の硫酸ニッケル結晶を生成し超電導バルクマグネット（3 T）を用いて，無電解ニッケルメッキ廃液からのニッケル を磁気分離回収も試みられている ${ }^{199}$ 。

包括法（Inclusion method）は，高分子材料や多孔質材お よび多孔質マイクロカプセルなどを用いて対象物質とマグ ネタイトとを一体的に固定し, 強磁性体として磁気分離・ 回収を図る方法である。例えば多孔質磁性吸着材による下 水処理水からのリンの回収と除去が超電導マグネットを用 いて行われている ${ }^{20)}$

\section{3 高勾配磁気分離と磁気フィルター}

磁気シーディング法により対象物質に磁性を付与したと しても, 完全な強磁性体にならない場合もある。その場合 には，より大きな磁気力を作用させる目的で，大きな勾配 磁場を作り出す高勾配磁気分離を用いることになる ${ }^{21)}$ 。前 述したように, 磁気力を大きくするには, 外部磁場の空間 勾配を大きく寸ることが有効であり, 実用的には磁気フィ ルターが用いられる。磁気フィルターは, 直径数十〜百数 $+\mu \mathrm{m}$ の強磁性細線のメッシュで構成される。Fig. 4 亿磁気
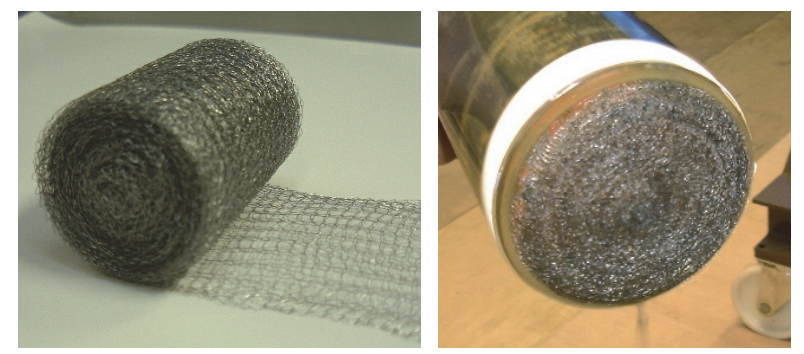

Fig. 4 Example of a magnetic filter. 
フィルターの例を示す。磁気フィルターに強磁場を印可す ると, 磁性細線が磁化され, その表面付近の磁場は極めて 大きな空間を持つ。これにより，磁性物質をフィルターの 磁性細線表面に効率よく吸着させたることができる。フィ ルターに吸着した対象物質は, フィルターを磁場外で洗浄 することにより除去できる。洗浄したフィルターは再度使 用可能となる。磁気フィルターは, ろ過膜フィルターと比 較すると，圧力損失が少なくポンプ動力費用が少ない，洗 浄が容易でフィルターを再利用できる, などの特徵を有し ている。

\section{4 磁気アルキメデス効果を利用した磁気分離}

式（1）からわかるように，流体などの周囲媒体と対象 物質の磁化率差があれば磁気力が発生する。この磁気力を 重力と対抗する方向に作用させれば，物質には浮力が発生 することになる。これを磁気アルキメデス効果 ${ }^{22)}$ と呼ぶ。 この効果を利用すれば, 周囲媒体の磁性を適切に選ぶこと により, 磁化率の小さい反磁性物質についても, 磁気シー ディングを用いずに, 超電導マグネットによる強磁場下で、 対象物質のサイズによらず，物質ごとに特定位置に浮上さ せることが可能となる。その力学的根拠は次の通りである。 磁気アルキメデス効果による磁性物質の浮上条件は以下の 式で表される（重力方向を $z$ とする）。

$$
-\rho_{1} g+\frac{\chi_{1}}{\mu_{0}} B \frac{\partial B}{\partial z}+\rho_{2} g-\frac{\chi_{2}}{\mu_{0}} B \frac{\partial B}{\partial z}=0
$$

ここで， $\rho_{1}$ と $\chi_{1}$ はそれぞれ対象物質の密度と磁化率， $\rho_{2}$ と $\chi_{2}$ はそれぞれ周囲媒体の密度と磁化率を表す。

複数の反磁性物質が媒体中に混ざっていても, 浮上安定 位置は物質ごとに異なる ${ }^{23)}$ 。この磁気浮上の安定位置の違 いを利用すれば, 反磁性物質の選択的な分離が可能になる。 この磁気アルキメデス磁気分離法は, 高勾配磁場を形成す る装置の工夫と周囲媒体の選択により, 反磁性物質のみな らず，常磁性物質の分離にも適用可能である。つまり，反 磁性物質と混ざった処理対象物質についても, それぞれの 物質で決まる安定浮上位置で分離が可能となるので, 有価 資源回収などへの適用が期待される ${ }^{24,25) 。}$

\section{5 磁場発生装置}

磁気分離に利用可能な磁場発生装置としては，希土類永 久磁石, 常伝導電磁石, 超電導マグネットが考えられる。 それぞれに磁場発生装置としての特徵があり, 磁気分離に 使用する場合には，磁場強度，発生空間と分離処理に必要 な空間との関係, 分離に必要な磁場分布, 装置コストや運 転コスト, 保守性, 適用場所での受容性などを考慮して選 択することが必要である。Fig. 5 は，これらの磁場発生装 置について, 磁場空間と磁場強度について整理したもので ある ${ }^{13)}$ 。

希土類永久磁石は, 開放空間の周辺端部で磁界勾配が高 く安価であるが, 最大磁場・磁場空間が小さいので, 強磁

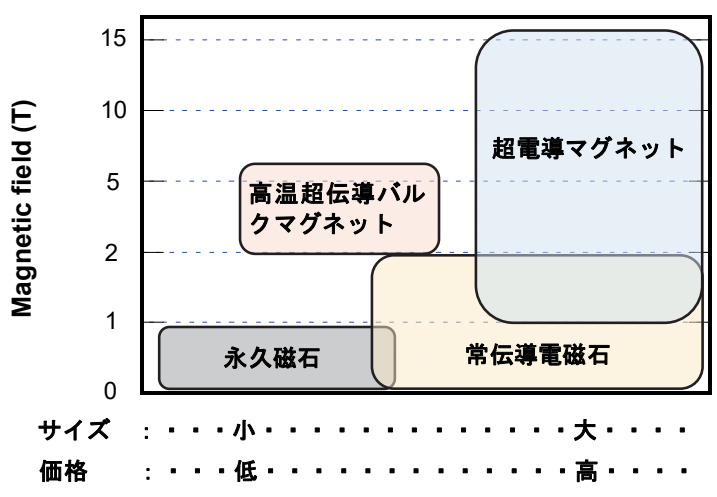

Fig. 5 Mapping of magnetic-field intensity, volume and price of various magnets.

性物質で且つ処理速度のあまり大きくない応用に都合が良 い。実際, 大学・研究所等の廃液処理 ${ }^{18)}$ や産業用の磁選

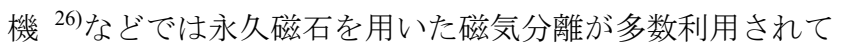
いる。また，比較的安価で手軽に利用できることから，ラ ボスケールの研究でもしばしば用いられる ${ }^{27) 。 ~}$

常伝導電磁石は, 水冷銅コイルと性能の良い電磁軟鉄 ヨークを用いれば, 最大磁場で $2 \mathrm{~T}$ 程度が得られる。磁場 空間を大きくするには大直径のヨークが必要になるので, 大重量となる。また必然的に, 銅コイルでのジュール損失 に相当する電力と水冷のための電力が必要になる。一方, 励消磁は比較的自由に行えるので, 磁気分離フィルターの 洗浄は容易になる。また, ヨークの構造を工夫すれば, コ イルと磁場発生空間を分離できるので, システムとしてレ イアウト設計の自由度が高くなる。

超電導マグネットでは, 無冷媒の伝導冷却マグネットが 開発され ${ }^{28)}$, 取扱い困難な液体へリウムを用いずに容易に 大空間に強磁場を発生できることから, 超電導分野だけで なく, 磁気分離等の研究用や一般民生用として, 広く普及 している。超電導マグネットを利用する最大の利点は, 大 空間に強磁場を省電力で発生できることである。磁気分離 技術において, 処理速度・処理量の増大に対して処理空間 の大型化は極めて有効であり, 高速大量処理が要求される 実用化ステージでは, 超電導マグネットは必須の技術要素 となる。近年開発が進んだ高温超電導バルクマグネット ${ }^{29)}$ は, 2-5 T の磁場を開放空間に発生できる磁場装置として の利用が期待されている。高温超電導バルクマグネットは 捕捉磁場強度・バルク材料の大きさ・製作コストの面で 「希土類系永久磁石以上, 超電導マグネット未満」の磁場 発生装置としての利用が考えられる。

\section{4. 超電導技術を応用した磁気分離研究の現状}

本章では，超電導技術を応用した磁気分離の研究開発の 現状について, まずこれまでの低温工学・超電導学会での 発表内容を総括し, それに基づいて国内の研究開発状況を 分析する。次に, 筆者が開催に携わっている日中韓の磁気 
分離関連のフォーラム IFMFC における発表・情報交換に 基づき，中国および韓国の状況を概説する。

\section{1 国内での研究開発状況}

低温工学・超電導学会では 2006 年度から磁気分離が正 式な発表カテゴリーになったこともあり，それ以降の大会 では, 磁気分離研究開発について活発に発表が行われてき ている。そのほとんどが, 超電導技術を応用した磁気分離 研究に関するものである。そこで，2006 年度から 2018 年 の間の磁気分離発表 ${ }^{30)}$ について Table 1 にまとめた。様々 な種類の産業廃棄物の分離無害化処理や再利用化, 有価資 源リサイクル，放射能污染土壤の処理について磁気分離技 術を適用寸る研究が行われていることが分かる。以下，利 用する磁場装置別に緾めてみたい。

\subsection{1 超電導マグネットを用いた磁気分離}

磁気シーディングを用いない磁気分離研究（Table 1 の A 項）としては，既存の分離対象物に常磁性または強磁性の 鉄酸化物が含まれている場合である。まず，火力発電所ボ イラー給水中の鉄酸化物スケールの除去（Table 1 の項目 1) が挙げられる。火力発電所ボイラーの熱交換効率の維持や $\mathrm{CO}_{2}$ 排出抑制に不可決である。本研究は既に実証スケール (実機の 1/7) での研究が行われている。また放射性セシウ ム污染土畩の減容化技術への適用を目指した研究も注目で きる（Table 1 の項目 2)。Cs との親和力の強い常磁性の バーミキュライト粘土成分を分級により抽出した後, 超電 導マグネットの強磁場内で HGMS により、Cs 濃度の高い 土壤を選択的に分離回収できる。

次に磁気シーディング法と高勾配磁気分離を併用して成 果を上げているのは, 各種の磁性吸着剂による産業廃水中 の污濁物質や河川の富栄養化成分の除去（Table 1 の項目 4), 高粘性流体中不純物除去（Table 1 の項目 5), 粉体輸 送中の磁気分離（Table 1 の項目 6), 温泉中のシリカ除去 (Table 1 の項目 7) などである。また磁気アルキメデス分 離については, 媒体の溶液中の溶存酸素量を増やすなどの 工夫をしながら，構造異性体の分離（Table 1 の項目 9), 非鉄金属やプラスティックの選別（Table 1 の項目 10）な どである。

\section{1.2 高温超電導バルクマグネットを用いた磁気分離}

小型で取り扱い容易な高温超電導バルクマグネットを利 用した磁気分離（Table 1のB 項）では, 磁気シーディング 無しの例として，鉄さびを含むドラム午洗浄水の浄化があ る（Table 1 の項目 12）。また磁気シーディング法と高勾配 磁気分離を併用した事例として, Ni メッキ廃液中の NI 回 収を目的に Ni 化合物の磁気分離（Table 1 の項目 13）, Cs やヒ素の磁気分離 (Table 1 の項目 14), 切削廃油の磁気分 離（Table 1 の項目 15), 磁気的遺伝子導入（Table 1 の項目 16）, など基礎的な研究が行われている。

\section{1 .3 永久磁石を用いた磁気分離}

希土類永久磁石を磁気分離に利用寸る利用する磁気分離
Table 1 List of presentations related to magnetic separation at CSJ conferences from 2006-2010 and CSSJ conferences from 2011-2018.

\begin{tabular}{|c|c|c|}
\hline \multicolumn{2}{|c|}{ A：超電導マグネット利用 } & 件数 \\
\hline $\begin{array}{l}\text { 磁気シー } \\
\text { ディング無 }\end{array}$ & $\begin{array}{l}\text { 1. 火力発電所ボイラー水中の酸化鉄ス } \\
\text { ケール除去 } \\
\text { 2. Cs 污染土㙥減容化 } \\
\text { 3. その他 }\end{array}$ & $\begin{array}{l}13 \\
10 \\
4\end{array}$ \\
\hline $\begin{array}{l}\text { 磁気シー } \\
\text { ディング有 }\end{array}$ & $\begin{array}{l}\text { 4. 磁性吸着材による污染物質除去 } \\
\text { 5. 高粘性流体中の不純物除去 } \\
\text { 6. 粉体輸送中の不純物分離 } \\
\text { 7. 温泉水中の } \mathrm{SiC} \text { 除去 } \\
\text { 8. その他 }\end{array}$ & $\begin{array}{l}7 \\
6 \\
5 \\
3 \\
8\end{array}$ \\
\hline $\begin{array}{l}\text { 磁気アルキ } \\
\text { メデス分離 }\end{array}$ & $\begin{array}{l}\text { 9. 構造異性体の磁気分離 } \\
\text { 10. 俳金属・プラスティの分離 } \\
\text { 11. その他 }\end{array}$ & $\begin{array}{l}2 \\
2 \\
3\end{array}$ \\
\hline \multicolumn{3}{|c|}{ B : 高温超電導バルクマグネット } \\
\hline $\begin{array}{l}\text { 磁気シー } \\
\text { ディング無 }\end{array}$ & 12. ドラム午洗浄液処理 & 4 \\
\hline $\begin{array}{l}\text { 磁気シー } \\
\text { ディング有 }\end{array}$ & $\begin{array}{l}\text { 13. } \mathrm{Ni} \text { 化合物の磁気分離 } \\
\text { 14. } \mathrm{Cs} \cdot \text { 素の磁気分離 } \\
\text { 15. 切削油廃液の磁気分離 } \\
\text { 16. 磁気的遺伝子導入 } \\
\text { 17. その他 }\end{array}$ & $\begin{array}{l}4 \\
3 \\
1 \\
1 \\
2\end{array}$ \\
\hline \multicolumn{3}{|c|}{$\mathrm{C}:$ 永久磁石利用 } \\
\hline & $\begin{array}{l}\text { 18. 畜産廃水中の抗生物質の分離 } \\
\text { 19. 粘土物質の分離 } \\
\text { 20. 磁化活性污泥法 }\end{array}$ & $\begin{array}{l}1 \\
1 \\
47\end{array}$ \\
\hline
\end{tabular}

研究について纏める (Table 1 の C 項)。適用例として, 畜 産廃水抗生物質分離（Table 1 の項目 18）、粘土物質磁気分 離（Table 1 の項目 19）などである。また市販の永久磁石 プレートを巧みに利用した磁化活性污泥法が多様な機能を 発揮していることも特筆される（Table 1 の項目 20）。この 磁化活性污泥法については, 超電導マグネットを適用すれ ば, 大容量化, 処理速度の向上, 処理費用の低減など, 大 型処理施設での実用化において大きなメリットがあること が指摘されている。

\section{2 中国・韓国での研究開発状況}

中国では, 経済発展に伴って顕在化した環境污染が深刻 になっており, 中国政府の環境基準の㛜格化と相まって, 日本の環境保全に向けた磁気分離技術に高い関心がある。 また国土が広いこともあり, 処理量が多いことから, 磁気 分離装置のサイズや処理量も大きいものが求められており, 超電導磁気分離技術の有用性が発揮できる。磁気分離で使 用する超電導マグネットは, それぞれの研究機関で磁気分 離専用として製作されている。Fig. 6 は, 中国で稼働中の カオリン粘土精製専用の超電導磁気分離装置 ${ }^{31)}$ である。5 $\mathrm{T}$ の超電導マグネットを用いた磁気分離により, 原料に含 まれる鉄分が $8.25 \%$ から $0.37 \%$ に低減できることが報告さ れている。

韓国では, 超電導応用技術開発を目的として, 研究用の 超電導磁気分離装置が韓国電気研究院 (KERI) で試作され た ${ }^{32)}$ 。現在はこの装置を使用して, 鉱山の漏水に含まれる 重金属やヒ素の磁気分離研究が国立安東大学で行われている。 


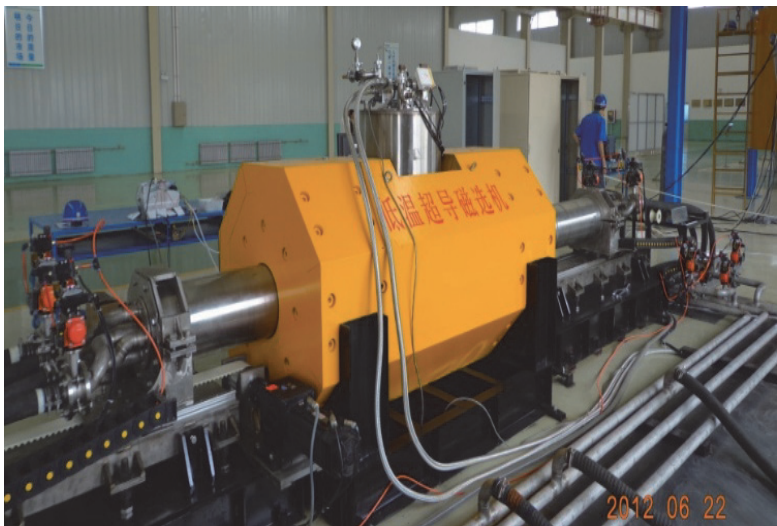

Fig. 6 Superconducting magnetic separator developed for iron removal from kaolin clay in China.

\section{5. 超電導磁気分離技術と社会ニーズ}

本稿では，超電導マグネットを用いた磁気分離技術を中 心に最近の研究成果の分析を試みた。超電導マグネットに よる強磁場を利用することにより, 強磁性物質のみならず, 常磁性物質や反磁性物質も含めた様々な物質を磁気分離で きることが示され，環境保全，資源循環などに貢献できる 技術であることが確認された。環境保全や無害化に向けた 研究における処理対象および分離された有害物質を Table 2 に䌂めた。Table 2 に示すように, 超電導マグネットによる 強磁場を利用する磁気分離技術が適用な可能な対象は，都 市下水, 最終処分場浸出水, 畜産廃水, 工場廃水, 湖水, 閉山の鉱山漏洩水, 高濃度セシウム污染土壤など多岐に及 ぶ。これらの研究のほとんどは国内のものであり，基礎研 究成果は大量に蓄積され, 社会実装への基盤は整ってきた。

2015 年に欧州連合（EU）において，「循環経済（Circular Economy)」の概念が提唱され，それに向けた行動計画が公 表された ${ }^{33)}$ 。この概念は，原材料の価值が可能な限り経済 の中で維持され, 廃棄物の発生がほとんどなく, 持続可能 な資源効率性の高い経済を実現するというものである。ア ジア・太平洋でも、日本の呼びかけで 39 か国が CE 社会実 現に向けた会議に参加し，2019 年には Bankoku 宣言による 行動計画を決めている ${ }^{34)}$ 。日本では 2018 年に, CE 社会実 現を推進するための組織「一般社団法人 サーキュラーエ コノミー推進機構」が創設された ${ }^{35)}$ 。またほぼ同じ時期で ある 2015 年の国連サミットにおいて，「持続可能な開発目 標（Sustainable Development Goals: SDGs）」が採択された ${ }^{36) 。 ~}$

これらにおいては，環境保全技術，資源循環技術はその 中核をなすものであり，今後国際的にも様々な技術開発・ 技術導入が進んでいくと予想される。本稿で分析したよう に，適用対象が多岐にわたり，2 次廃棄物がほとんど発生 しないという特徴を有する超電導磁気分離技術は，このよ うな持続的成長社会の実現に向けた技術開発において的確 な技術であると考えられる。一方，本稿でも紹介したよう
Table 2 List of wastes treated and hazardous substances separated using magnetic separation technology.

\begin{tabular}{|l|l|}
\hline \multicolumn{1}{|c|}{ 処理対象 } & \multicolumn{1}{|c|}{ 分離された有害物質 } \\
\hline 都市下水 & $\begin{array}{l}\text { 窒素, リン, BOD, COD, 有機化合物, 難分解 } \\
\text { 性物質 }\end{array}$ \\
\hline $\begin{array}{l}\text { 埋立地浸出 } \\
\text { 水 }\end{array}$ & $\begin{array}{l}\text { 窒素, リン, BOD, COD, 有機化合物, 難分解 } \\
\text { 性物質 }\end{array}$ \\
\hline 畜産廃水 & 窒素, リン, BOD, COD, 懸濁物質, 抗生物質 \\
\hline 工業廃水 & 懸濁物質, 染料, セルロース, 金属・非鉄金属 \\
\hline 湖水 & 窒素, リン, BOD, COD, アオコ, クロレラ \\
\hline 鉱山漏洩水 & 重金属, ヒ素, 酸化鉄 \\
\hline $\begin{array}{l}\text { 放射能污染 } \\
\text { 土壌 }\end{array}$ & 放射性セシウム \\
\hline
\end{tabular}

に, 超電導磁気分離技術の普及に向けた研究会活動や啓 蒙・教育活動が継続的に行われ, また本学会でも多数の研 究発表が行われているものの, 実産業界での認知度は未だ 高いとは言い難い。超電導技術の実用化については, エネ ルギーや輸送の分野では, イノベーション効果と経済効果 が認識されて継続的な開発支援 ${ }^{37)}$ が行われている。また医 療分野についても，先端医療に不可欠なイノベーション技 術として導入され, 性能向上のための開発努力が続けられ ている ${ }^{38)}$ 。超電導磁気分離技術については, 導入が期待さ れている環境修復や資源回収などの分野での, イノベー ション効果, 経済効果などの点での優位性を明確にするこ とが求められる。これからは、超電導磁気分離技術の優位 性について, 積極的に社会に情報発信を行っていくととも に, 我が国で蓄積された超電導磁気分離に関する技術資源 を, 実社会のニーズや国際情勢に対応して, 的確にマッチ させて展開できる体制作りが必要になると考えられる。

最後に, 本稿作成に当たり, 多くの方々から情報の提供 をいただきました。この紙面をかりてお礼申し上げます。

\section{参 考 文 献}

1) C. G. Gunther: "Electro-Magnetic Ore Separation", Hill Publishing Company, New York (1909)

2) 電気学会 公害対策電気技術常設専門委員会編：「大勾配磁気 分離技術の現状と動向」電気学会技術報告書 第 114 号 (1981)

3) 西嶋茂宏：「特集「磁気分離」に寄せて」低温工学 46 (2011) 616

4) T. Ohara: "Progress of magnetic separation technology for processing a large quantity of dilute suspension", TEION KOGAKU 46 (2011) 617-628 (in Japanese)

小原健司：「大量希薄懸濁系処理への磁気分離技術応用に関す る研究開発」, 低温工学 46 (2011) 617-678

5) 電気学会 磁気力制御を利用した超電導技術の実用化の現状及 び新たな展開調查専門委員会編 :「磁気力制御を利用した超電 導技術の実用化の現状及び新たな展開」, 電気学会技術報告 第 1288 号 (2013) 
6) S. Nishijima, Y. Akiyama, F. Mishima : "Study on decontamination of radioactive cesium form soil by magnetic separation" Abstracts of CSSJ Conference 86 (2012) 192 (in Japanese)

西嶋茂宏, 秋山庸子, 三島史人：「磁気分離法を用いた放射性 物質の土㗒からの除去に関寸る研究」, 2012 年度秋季低温工 学・超電導学会講演概要集 (2012) 192

7) 環境省：環境研究総合推進費終了研究等成果報告書「セシウ ムの動態解析に基づく除染シナリオの構築と磁気力制御型除 染法の開発」（5-1301）平成 25 年度～平成 26 年度 (2015)

8) K. Sekiya, H. Kuwahara Y. Yoshida, S. Igarashi, N. Nomura, F. Mishima, Y. Akiyama and S. Nishijima: "Study on decontamination of contaminated soils by magnetic separation", IEEE Trans. Appl. Supercond. 243 (2014) 3700205

9) Y. Yoshida, K. Sekiya, N. Nomura, F. Mishima, Y. Akiyama and S. Nishijima: "Study on volume reduction of contaminated soil by radioactive cesium using the magnetic separation", IEEE Trans. Appl. Supercond. 253 (2015) 3700505

10) 例えば, 物質・材料研究機構 材料研究所強磁場研究グ ループ主催：「磁気分離研究開発に関するワークショップ成果 報告集 TML Annual Report supplement 1」(2000), (2001), (2002)

11）磁気力制御研究会 : http://www2.kobe-u.ac.jp/ ihara72/ms/index.html

12) The $10^{\text {th }}$ International Forum on Magnetic Force Control in Nara, Aug. 28-30, 2019: http://www.see.eng.osaka-u.ac.jp/seeqb/seeqb/IFMFC/2019/index.html

13）電気学会 物質の磁気特性を活用した精密磁気制御応用技術調 查専門委員会編：「物質の磁気特性を活用した精密磁気制御応 用技術の現状と動向」, 電気学会技術報告 第 1198 号 (2010)

14) S. Takeda: "Magnetically seeding processes", TEION KOGAKU 37 (2002) 315-320 (in Japanese)

武田真一：「磁気分離のための担磁法」，低温工学 37 (2002) 315-320

15) S. Nishijima and S. Takeda: "Research and development of superconducting high gradient magnetic separation for purification of wastewater from paper factory", IEEE Trans. Appl. Supercond. 172 (2007) 2311-2314

16) S. Nishijima, Y. Izumi, S. Takeda, H. Suemoto, A. Nakahira and S. Horie: "Recycling of abrasives from wasted slurry by superconducting magnetic separation", IEEE Trans. Appl. Supercond. 132 (2003) 1596-1599

17）三橋和成, 吉崎亮造, 岡田秀彦, 小原健司, 和田 仁 : 「超伝 導磁石を用いる環境ホルモン除去磁気分離システムの開発」, 化学分析 522 (2003) 121-126

18）辻 俊郎, 菅野 出, 清水 恵己, 榊原直孝:「フェライト法 による重金属排水処理」，環境技術 48 (1975) 564-568

19) T. Oka, T. Kimura, D. Mimura, H. Fukazawa, S. Fukui, J. Ogawa, T. Sato, M. Ooizumi, K. Yokoyama, M. Tsujimura and T. Terasawa: "Magnetic precipitate separation for Ni plating waste liquid using HTS bulk magnets", Physica C 484 (2013) 325-328

20) T. Ishiwata, O. Miura, K. Hosomi, K. Shimizu, D. Ito and Y. Yoda: "Removal and recovery of phosphorus in wastewater by superconducting high gradient magnetic separation with ferromagnetic adsorbent", Physica C 47020 (2010) 1818-1821

21) T. Ohara: "Particle capture theory and experiment on an amorphous magnetic ribbon filter", IEEE Trans. Magn. 202 (1984) 436-443

22) Y. Ikezoe, N. Hirota, J. Nakagawa and K. Kitazawa: "Making water levitate", Nature 3936687 (1998) 749
23) N. Hirota, Y. Ikezoe, H. Uetake, T. Kaihatsu, T. Takayama and K, Kitazawa: "Magneto-Archimedes levitation and its application", RIKEN Review 44 (2002) 159

24) Y. Matsubara, O. Miura: "Fundamental study for resource recovery from urban mine by magneto-Archimedes effect”, IEEE Trans. Appl. Supercond. 264 (2016) 7452372

25) Y. Ueda, F. Mishima, Y. Akiyama and S. Nishijima: "Fundamental study of plastic separation utilizing magnetic force" IEEE Trans. Appl. Supercond. 243 (2014) 3700805

26) 例えば, 日本磁力選鉱 (株)：http://www.nmd.co.jp/recycle/entry47.html

27) I. Ihara, K. Toyoda, N. Beneragama, K. Umetsu: "Magnetic separation of antibiotics by electrochemical magnetic seeding" J. Phys.: Conf. Ser. 156 (2009) 012034

28) K. Watanabe, et al.: " $(\mathrm{Nb}, \mathrm{Ti})_{3} \mathrm{Sn}$ superconducting magnet operated at $11 \mathrm{~K}$ in vacuum using high- $T_{\mathrm{c}}(\mathrm{Bi}, \mathrm{Pb})_{2} \mathrm{Sr}_{2} \mathrm{Ca}_{2} \mathrm{Cu}_{3} \mathrm{O}_{10}$ current leads", Jpn. J. Appl. Phys. 32 (1993) L488

29) N. Saho, K. Matsuda and N. Nishijima: "Palm-size miniature superconducting bulk magnet”, Cryogenics 52 (2012)604-608

30) 低温工学・超電導学会 :

https://www.csj.or.jp/conference/record.html

31) Z. Zian and W. Meifen: "Recent development of high gradient superconducting magnetic separator flor kaolin in China", Prog. in Superconductivity and Cryogenics 191 (2017) 5-8

32) J. E. Kim, D. W. Ha and Y. H. Kim: "Separation of steel slag from landfill waste for the purpose of decontamination using a superconducting magnetic separation system", IEEE Trans. Appl. Supercond. 253 (2015) 3700404

33) European Circular Economy Stakeholder Platform: https://circulareconomy.europa.eu

34) Final Bangkok 3R Declaration adopted on 6 March 2019: http://www.uncrd.or.jp/Home?page=view\&nr=1174\&type=13\&men $\mathrm{u}=198$

35) 一般社団法人 サーキュラー・エコノミー推進機構 : http://ceoc.or.jp

36) The United Nations: https://www.un.org/sustainabledevelopment/

37) 新エネルギー・産業技術研究開発機構：「超電導分野の技術戦 略策定に向けて」, 技術開発研究センターレポート4 (2015)

38）新エネルギー・産業技術研究開発機構 高温超電導実用化促進 技術開発 : https://www.nedo.go.jp/activities/ZZJP_100120.html

渡辺恒雄 1944 年 2 月 19 日生。1966 年京都大学 工学部電気第二工学科卒業。1968 年同大学院工学研究科博士前 期課程（電気工学専攻）修了。1968 年(財)電力中央研究所勤務。 ガス絶縁設計, 電気集塵装置高度化に従事。1991 年東京都立大 学工学部教授。主に電気と磁場を利用した環境保全技術開発に従 事。低温工学・超電導学会, 電気学会, 日本磁気科学会会員。工 学博士。

福 井聡 1969 年 2 月 3 日生。1992 年横浜国立大学 工学部電子情報工学科卒業。1 997 年同大学院工学研究科博士後 期課程電子情報工学専攻修了。同年新潟大学工学部助手。1999 年同助教授。2 014 年同教授。主に, 交流超電導導体・コイルの 電磁現象, 超電導電気機器の基礎研究に従事。低温工学・超電導 学会, 電気学会, 日本磁気科学会会員。博士 (工学)。 